ISSN 1112-9867

\title{
ALUMINUM TOXICITY IN ACID SULFATE SOIL ALLEVIATED WITH BIOGENIC LIMING COMPOSITES OF BLOOD COCKLE SHELL AND PALM KERNEL SHELL
}

\author{
N. M. A. Salleh ${ }^{1}$, C. F. Ishak ${ }^{2}$, A. Saat ${ }^{1}$ and S. K. Yong ${ }^{1, *}$ \\ ${ }^{1}$ Faculty of Applied Sciences, Universiti Teknologi MARA, 40450 Shah Alam, Selangor, \\ Malaysia \\ ${ }^{2}$ Department of Land Management, Faculty of Agriculture, Universiti Putra Malaysia, \\ Serdang, Selangor, Malaysia
}

Published online: 10 November 2017

\begin{abstract}
Low crop yield from acid sulfate soil was caused by high concentrations of aluminum and iron in soil. Aluminum ion which cause root injury at root region inhibits the uptake of the nutrients by the root and lead to nutrient deficiency. Ground magnesium limestones can be applied to overcome this problem but incurred more production cost. Biogenic liming agent from blood cockle shell and/or palm kernel shell are more cost effective and provide the essential element i.e. calcium. This study evaluate phase-association of Al in acid sulfate soil remediated using biogenic composites liming material using selective sequential extraction analysis. Biogenic liming composites were characterized for $\mathrm{pH}$, proximate analysis and elemental composition. High ratio of $\mathrm{BCS}$ in composite retained $\mathrm{Al}$ in the residual form about 91.33\%. Amelioration of soil with $100 \%$ PKS did not give significant reduction of the exchangeable Al.
\end{abstract}

Keywords: soil remediation; phytotoxicity; abiotic stress; calcination; alkalinity.

Author Correspondence, e-mail: yongsk@salam.uitm.edu.my

doi: http://dx.doi.org/10.4314/jfas.v9i6s.46 


\section{INTRODUCTION}

Low yield production of crops is one of the main issues in the agricultural sector. A major factor which contributed towards this issue is related with abiotic stress. Abiotic stress can be initiated by the non-living agents such as soil $\mathrm{pH}$ conditions, imbalance of plant nutrients, air pollutants or water stress. Nutrient imbalance in plant is influenced by the relationships with soil $\mathrm{pH}$ conditions. Fig. 1 illustrates nutrient availability as a function of the soil $\mathrm{pH}$ values and some plant growth best at soil $\mathrm{pH} 5.5$ to 6.5 [1]. The availability of toxic elements such as $\mathrm{Al}$ increased when soil $\mathrm{pH}$ value decreases. Such scenario may occur when the sulfide-rich soils are oxidized to create sulfuric acid in the soils. In Malaysia, coastal plain area such in Kedah-Perlis zones are facing with this condition related with acid sulfate soil.

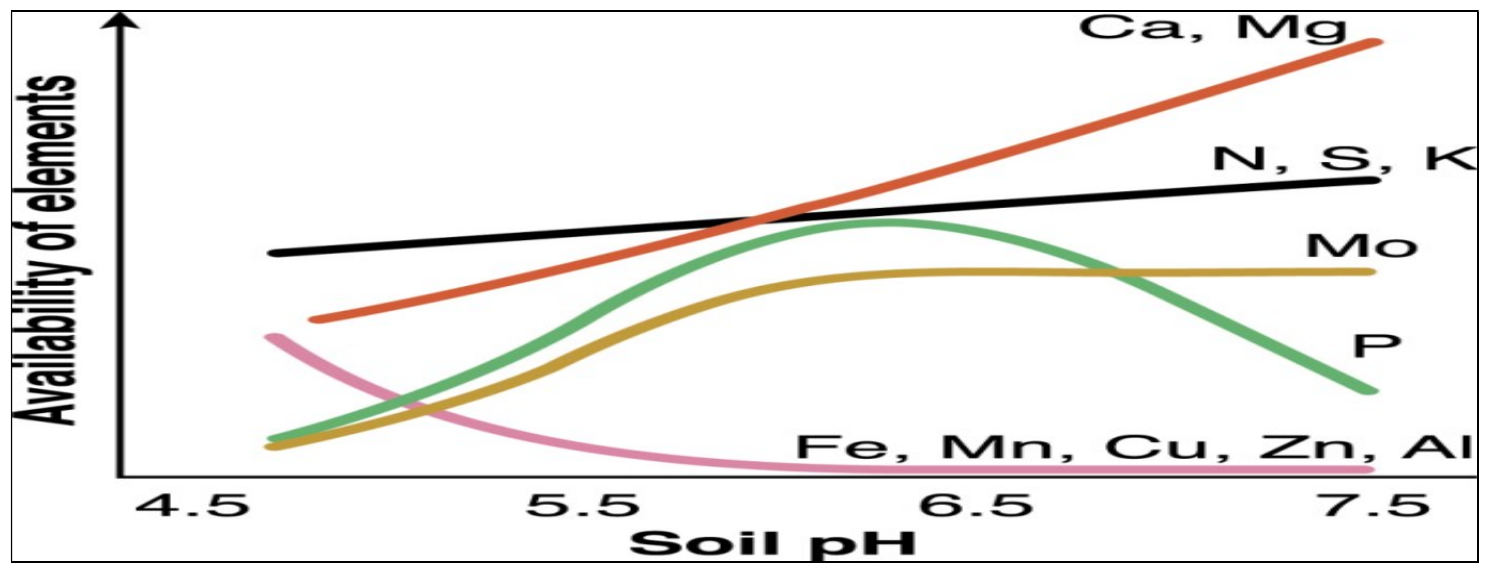

Fig.1. Effect of pH on nutrient availability [2]

Growth and yield of paddy at the granary area of Kedah-Perlis coastal plains are affected due to presence of acid sulfate soils [3]. Major area affected by acid sulfate soil is Merbok in the Sungai Petani district. Acid sulfate soil is a problematic soil, with low $\mathrm{pH}$ value $(<4)$ and high concentration of $\mathrm{Al}$ and $\mathrm{Fe}$ in soil. Aluminum toxicity severely affects the granary area in Merbok especially during the dry first cultivation season. Amelioration of Merbok soil has been carried out using lime [3], basalt [4] or calcium silicate [5]. Soil pH increased with amendment application and reduced $\mathrm{Al}$ toxicity.

The high availability of $\mathrm{Al}$ in the soil may cause root injury which inhibit the uptake of nutrient (i.e. phosphorus) by root. This condition leads to phosphorus deficiency of paddy. Deficiency of phosphorus can be traced by narrow, short and very erect dark green leaves [6]. Aluminum is strongly bound to insoluble inorganic matter and plant roots are not able to absorb this metal at 
$\mathrm{pH} 5.5$ or higher. However, $\mathrm{Al}$ in soil solution increase at $\mathrm{pH}<5.5$ [7] and is bioavailable that may be harmful to growth of plant [3].

Alleviation of aluminum phytotoxicity can be conducted by application of commercial liming materials (i.e. ground magnesium limestone [8, 3], basalt [4] or calcium silicate [5]. Commercial liming materials ameliorate the soil by increasing the $\mathrm{pH}$ and immobilize the heavy metals. Unfortunately, production of these commercial liming materials come from non-renewable source i.e. limestone mining quarry. Consequently, this may lead to depletion of the limestone, and may cause pollution to the air and water resources. As an alternative, waste BCS and palm oil milling biomass (i.e., PKS) can be manipulated as biogenic liming agents. BCS and PKS were selected as it is a highly abundant waste material. Addition of BCS and/or PKS may ameliorate soil acidity by providing calcium, magnesium or other nutrient element. Soil $\mathrm{pH}$ may be increased by addition of the liming materials and immobilized $\mathrm{Al}^{3+}$ as gibbsite $\left(\mathrm{Al}(\mathrm{OH})_{3}\right)$. To the best of our knowledge, there has been no report on the phase-association of $\mathrm{Al}$ in the ameliorated acid sulfate soil.

The objectives of this study are (1) to evaluate the potential of using composites of BCS and PKS as liming material and (2) to investigate Al phase-association in the remediated acid sulfate soil using selective sequential extraction analysis.

\section{EXPERIMENTAL}

\subsection{Feedstock Collection and Preparation}

Blood cockle shell was collected at Sabak Bernam, Selangor. Cleaning of as-received blood cockle shell was carried out by boiling with deionized water for 2 hours. Then, the shell was oven-dried for 72 hours and pulverized to $75 \mu \mathrm{m}$ in particle diameter. Palm kernel shell from palm oil milling factory in Jengka, Pahang was sun-dried and oven-dried for 48 and 24 hours respectively. Palm kernel shell was pulverized to $75 \mu \mathrm{m}$ in particle diameter. Pulverized BCS and PKS were kept in polyethylene zip lock bags.

\subsection{Combustion of Biogenic Composites Liming Material}

Biogenic composites material of BCS and PKS were initially blended and homogenized at various weight ratios (i.e., 1:0, 1:1 and 0:1). About 10 grams of each composite were transferred into uncovered crucible, and were combusted at $900^{\circ} \mathrm{C}$ for 1 hour under ambient 
condition. Composites ash were later cooled in the desiccator and kept in polyethylene zip lock bags.

\subsection{Characterization of Biogenic Composites Liming Material}

Two grams of samples (raw or ash) were mixed with $20 \mathrm{~mL}$ of $10 \mathrm{mM} \mathrm{CaCl}_{2}$ and the $\mathrm{pH}$ values were determined using a calibrated $\mathrm{pH}$ meter. Proximate analysis was conducted with thermogravimetric analyzer (TGA/DSC 1 Star System, Mettler Toledo, USA) using $20 \mathrm{mg}$ composites samples at $900^{\circ} \mathrm{C}$ peak temperature, $10^{\circ} \mathrm{C} / \mathrm{min}$ of heating rate and the air flow rate was $50 \mathrm{~mL} / \mathrm{min}$. Ultimate analysis was carried out using CHNS analyzer (Flash 2000 Organic Elemental Analysis, Thermo Scientific, USA). Elemental composition of biogenic composites liming material was determined using X-ray fluorescence (XRF) spectroscopy (Epsilon3-XL PANalytical, Netherlands).

\subsection{Soil Collection}

Sampling of acid sulfate soil was conducted at paddy field at Kampung Padang Tok Sura, Merbok, Kedah, Malaysia (5.711128N, 100.384416E). Soil samples were collected at $30 \mathrm{~cm}$ interval, and to the depth of $0-15 \mathrm{~cm}$ (topsoil) using a soil auger. Soil sampling was conducted before paddy cultivation for first season (April-August 2016) and the condition was dry during this season.

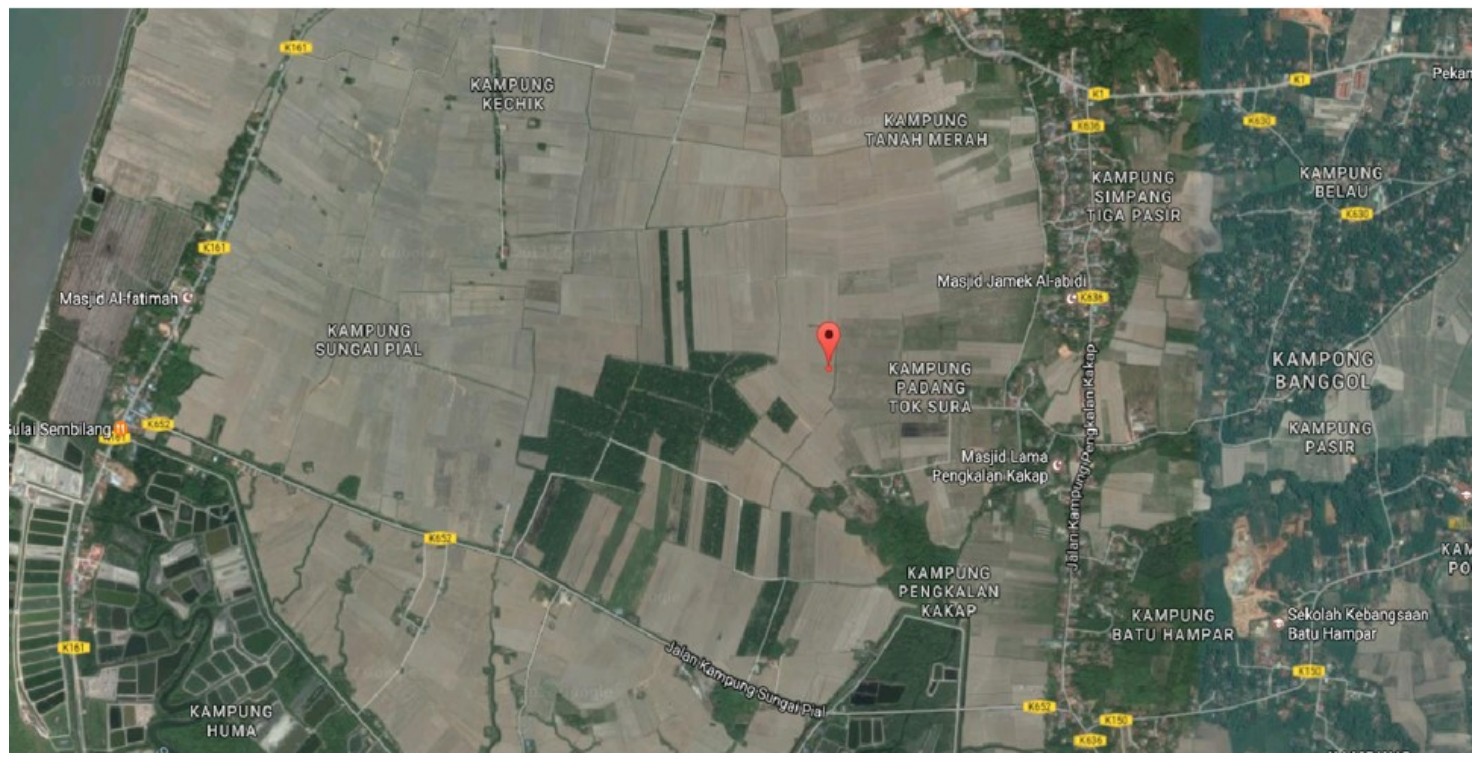

Fig.2. Soil sampling location at Kampung Padang Tok Sura, Merbok, Kedah, Malaysia $(5.711128 \mathrm{~N}, 100.384416 \mathrm{E})$ 


\subsection{Soil Analyses}

Samples of soil were air-dried, ground and passed through a $2 \mathrm{~mm}$ sieve prior to chemical analyses. Soil $\mathrm{pH}$ was determined on soil slurry at soil-solution ( $10 \mathrm{mM}$ calcium chloride) ratio of 1:2.5 using a calibrated glass electrode $\mathrm{pH}$ meter. Soil particle distribution was determined using the hydrometer method. Cation exchange capacity (CEC) was determined using $1 \mathrm{M}$ $\mathrm{NH}_{4} \mathrm{OAc}$ at $\mathrm{pH} 7$ [9]. Soil organic matter was determined using loss-on-ignition method. Exchangeable Al was determined by extracting 5 gram of soil with $50 \mathrm{~mL}$ of $1 \mathrm{M} \mathrm{KCl}$. The mixture shaken for 30 minutes and ICP-OES was used to analyze extracted Al.

\subsection{Soil Incubation Study}

Soil samples for incubation study were air-dried for 5 to 7 days, ground and sieved through 2 mm sieve (mesh no.10). Then, the soil samples were homogenized with biogenic composites liming materials with application rates of $2 \mathrm{~g}$ liming materials to $1 \mathrm{~kg}$ soil (4 Mg/ha) (Table 1$)$. Initial and final $\mathrm{pH}$ was recorded during soil incubation period on day 0 and day 21 respectively. Soil incubation was carried out for 3 consecutive weeks (21 days).

Table 1. Soil incubation study treatments and application rate

\begin{tabular}{cc}
\hline Treatments & Application Rate \\
\hline Soil 100\% (control) & No amendment \\
Raw 0:1(BCS:PKS) & $4 \mathrm{Mg} / \mathrm{ha}$ \\
Raw 1:1(BCS:PKS) & $4 \mathrm{Mg} / \mathrm{ha}$ \\
Raw 1:0(BCS:PKS) & $4 \mathrm{Mg} / \mathrm{ha}$ \\
GML & $4 \mathrm{Mg} / \mathrm{ha}$ \\
CaCO 3 & $4 \mathrm{Mg} / \mathrm{ha}$ \\
$900^{\circ} \mathrm{C} \mathrm{0:1(BCS:PKS)}$ & $4 \mathrm{Mg} / \mathrm{ha}$ \\
$900^{\circ} \mathrm{C} \mathrm{1:1(BCS:PKS)}$ & $4 \mathrm{Mg} / \mathrm{ha}$ \\
$900^{\circ} \mathrm{C} \mathrm{1:0(BCS:PKS)}$ & $4 \mathrm{Mg} / \mathrm{ha}$ \\
\hline
\end{tabular}

\subsection{Selective Sequential Extraction (SSE) Analysis}

Analysis of selective sequential extraction for soil samples were carried out after soil incubation period was completed. Five major fractions of soil $\mathrm{Al}$ : exchangeable, bound to carbonate, bound to manganese oxide, bound to organic matter and residual were determined [10-12]. 


\subsubsection{Fraction 1: Exchangeable}

One gram of soil samples were extracted at room temperature for 1 hour with $8 \mathrm{~mL}$ of magnesium chloride hexahydrate $\left(1 \mathrm{M} \mathrm{MgCl}_{2} \cdot 6 \mathrm{H}_{2} \mathrm{O}, \mathrm{pH} 7.0\right)$ with continuous agitation (end-to-end shaker, $35 \mathrm{rpm}$ ). Once the extraction was completed, the soil samples were centrifuged at $4000 \mathrm{rpm}$ for 10 minutes. Supernatant from the samples were filtered by using $0.45 \mu \mathrm{m}$ syringe filter and deionized water were added about $8 \mathrm{~mL}$ into the filtered supernatant.

\subsubsection{Fraction 2: Bound to Carbonate}

The residue from Fraction 1 was leached at room temperature with $8 \mathrm{~mL}$ of $1 \mathrm{M} \mathrm{NaOAc}$ (adjusted to pH 5.0 with 100\% glacial acetic acid, HoAc). Continuous agitation (end-to-end shaker, $35 \mathrm{rpm}$ ) was maintained and the time necessary for complete extraction was determined to be 3 hours. Once the extraction was completed, the soil samples were centrifuged at 4000 rpm for 10 minutes. Supernatant from the samples were filtered by using $0.45 \mu \mathrm{m}$ syringe filter and deionized water were added about $8 \mathrm{ml}$ into the filtered supernatant.

\subsubsection{Fraction 3: Bound to Iron and Manganese Oxide}

Residue from Fraction 2 was extracted with $20 \mathrm{~mL}$ of $0.04 \mathrm{M} \mathrm{NH}_{2} \mathrm{OH} . \mathrm{HCl}$ in $25 \%$ (v/v) HoAc. This fraction experiment was performed at $95^{\circ} \mathrm{C}$ with occasional agitation for 6 hours. Once the extraction was completed, the soil samples were centrifuged at $4000 \mathrm{rpm}$ for 10 minutes. Supernatant from the samples were filtered by using $0.45 \mu \mathrm{m}$ syringe filter.

\subsubsection{Fraction 4: Bound to Organic Matter}

Three milliliter $0.02 \mathrm{M} \mathrm{HNO}_{3}$ and $5 \mathrm{~mL} 30 \% \mathrm{H}_{2} \mathrm{O}_{2}$ ( $\mathrm{pH}$ adjusted with $\mathrm{HNO}_{3}$ to $\mathrm{pH}$ 2) was added to the residue from Fraction 3 and the mixture was heated to $85 \pm 2^{\circ} \mathrm{C}$ for 2 hours with occasional agitation. After 2 hours, $3 \mathrm{~mL} 30 \% \mathrm{H}_{2} \mathrm{O}_{2}$ ( $\mathrm{pH}$ adjusted with $\mathrm{HNO}_{3}$ to $\mathrm{pH}$ 2) were added and continue heating for another 2 hours at $85 \pm 2^{\circ} \mathrm{C}$ with occasional agitation. Once the samples were cooled down, add $5 \mathrm{~mL} 3.2 \mathrm{M} \mathrm{NH}_{4} \mathrm{OAc}$ in $20 \%$ (v/v) $\mathrm{HNO}_{3}$ (dilute to $20 \mathrm{~mL}$ ) and mixed with continuous agitation for 30 minutes. Once the extraction was completed, the soil samples were centrifuged at $4000 \mathrm{rpm}$ for 10 minutes. Supernatant from the samples were filtered by using $0.45 \mu \mathrm{m}$ syringe filter.

\subsubsection{Fraction 5: Residual}

The residue from Fraction was digested with $9 \mathrm{~mL}$ concentrated $\mathrm{HCl}$ and $3 \mathrm{~mL}$ concentrated $\mathrm{HNO}_{3}$ in a microwave digester according to EPA method 3051 and diluted 50:1 with $18 \mathrm{~m} \Omega$ DI 
water. Final dilution was filtered through a $0.45 \mu \mathrm{m}$ syringe filter and stored at $4^{\circ} \mathrm{C}$. Once the entire sequential extraction was completed, the samples were analyzed using inductively couple plasma- optical emission spectrometer (ICP-OES) according to EPA method 6010B.

\subsection{Statistical Analyses}

All measurement in the characterization of composites and SSE analyses were conducted in duplicates, mean values and standard deviation were computed using Microsoft Excel for the data obtained from analysis.

\section{RESULTS AND DISCUSSION}

Table 2 shows the $\mathrm{pH}$ values of the biogenic liming material (raw and calcined). Increasing the content of $\mathrm{BCS}$ in the raw composites material causes the increasing $\mathrm{pH}$ values from 5.84 to 10.02. Calcination of biogenic liming material at $900^{\circ} \mathrm{C}$ also increased the $\mathrm{pH}$ with $900^{\circ} \mathrm{C} 1: 1$ has the highest $\mathrm{pH}$ compared to others composites.

Table 2. $\mathrm{pH}$ of biogenic liming material (raw and calcined)

\begin{tabular}{ccc}
\hline & \multicolumn{2}{c}{$\mathbf{p H}$} \\
Composite Ratio (BCS:PKS) & Raw & $\mathbf{9 0 0}^{\circ} \mathbf{C}$ \\
\hline $0: 1$ & 5.84 & 9.24 \\
$1: 1$ & 6.40 & 13.23 \\
$1: 0$ & 10.02 & 13.12 \\
\hline
\end{tabular}

Proximate and ultimate analysis of biogenic liming material is illustrated in Table 3 and 4 respectively. Pure BCS, (i.e., 1:0) generated more ash as compared to pure PKS (i.e., 0:1). Lignocellulosic component in PKS contains high percentage of carbon as compared to other composites material. 
Table 3. Proximate analysis of biogenic liming material

\begin{tabular}{ccccc}
\hline \multirow{2}{*}{$\begin{array}{c}\text { Samples } \\
\text { (BCS: PKS) }\end{array}$} & Moisture & Volatile & Fixed & Ash \\
& Content (\%) & Matter (\%) & Carbon (\%) & Contents (\%) \\
\hline $0: 1$ & 4.83 & 21.89 & 47.11 & 26.17 \\
$1: 1$ & 2.28 & 18.69 & 36.77 & 42.26 \\
$1: 0$ & 0.50 & 0.00 & 31.67 & 68.33 \\
\hline
\end{tabular}

Table 4. Ultimate analysis of biogenic liming material

\begin{tabular}{ccccc}
\hline \multirow{2}{*}{ Samples } & \multicolumn{4}{c}{ Ultimate Analysis } \\
(BCS: PKS) & Nitrogen (\%) & Carbon (\%) & Hydrogen (\%) & Sulfur (\%) \\
\hline $0: 1$ & 0.02 & 46.79 & 5.76 & 0.00 \\
$1: 1$ & 0.00 & 11.60 & 0.01 & 0.00 \\
$1: 0$ & 0.00 & 11.63 & 0.13 & 0.00 \\
\hline
\end{tabular}

Table 5 illustrates elemental composition of biogenic liming materials from X-ray fluorescence (XRF) spectrophotometer. Calcined BCS (i.e., $900^{\circ} \mathrm{C}$ 1:0) contained the most calcium oxide $(\mathrm{CaO})$ content at $61.4 \%$. Silicon oxide $\left(\mathrm{SiO}_{2}\right)$ in of calcined PKS (i.e., $\left.900^{\circ} \mathrm{C} 0: 1\right)$ was highest as compared to other materials at 55.2\%. Calcium oxide content increased as the BCS content in the composite increased. Calcination of biogenic liming composites at $900^{\circ} \mathrm{C}$ produced more calcium oxide as compared to raw composites due to liberation of carbon dioxide from calcium carbonate in the BCS. 
Table 5. Biogenic composites liming materials elemental composition

\begin{tabular}{|c|c|c|c|c|c|c|}
\hline \multirow{2}{*}{$\begin{array}{l}\text { BCS: PKS } \\
\text { Composites }\end{array}$} & \multicolumn{6}{|c|}{ Elemental Composition (\%) } \\
\hline & $\mathrm{CaO}$ & $\mathbf{K}_{2} \mathbf{O}$ & MgO & $\mathrm{Al}_{2} \mathrm{O}_{3}$ & $\mathrm{Fe}_{2} \mathrm{O}_{3}$ & $\mathrm{SiO}_{2}$ \\
\hline Raw $0: 1$ & 0.52 & 1.54 & 3.85 & 3.76 & 6.70 & 7.26 \\
\hline Raw $1: 1$ & 37.7 & 0.68 & 4.37 & 7.62 & 1.21 & 4.52 \\
\hline Raw 1:0 & 55.7 & 0.14 & 4.08 & 6.45 & 0.07 & 0.95 \\
\hline $900^{\circ} \mathrm{C} 0: 1$ & 1.80 & 5.42 & 4.35 & 15.87 & 20.07 & 55.2 \\
\hline $900^{\circ} \mathrm{C} 1: 1$ & 56.7 & 0.60 & 5.56 & 8.65 & 1.23 & 6.20 \\
\hline $900^{\circ} \mathrm{C} 1: 0$ & 61.4 & 0.17 & 3.52 & 7.84 & 0.06 & 0.78 \\
\hline
\end{tabular}

Effect of commercial and raw biogenic composites liming materials on soil $\mathrm{pH}$ at the application rate of $2 \mathrm{~g} / \mathrm{kg}$ soil is illustrated in Fig. 3. Raw 1:0 composite liming materials increased the initial soil $\mathrm{pH}$ (i.e., 3.14) to maximum of $\mathrm{pH} 6.48$ on the $9^{\text {th }}$ day of incubation. The trend of soil $\mathrm{pH}$ incubated with GML and calcium carbonate are similar for the first 9 days of incubation. Presence of $\mathrm{CaO}(55.7 \%)$ in the raw BCS helped increased soil $\mathrm{pH}$ and reduced soil acidity. Reduction of $\mathrm{pH}$ value after 9 days of incubation may due to following dissolution reaction:

(i) $\mathrm{CaCO}_{3}+\mathrm{H}_{2} \mathrm{O}+\mathrm{CO}_{2} \rightarrow \mathrm{Ca}^{2+}+2 \mathrm{HCO}_{3}^{-}$

(ii) $\mathrm{MgCa}\left(\mathrm{CO}_{3}\right)_{2}+2 \mathrm{H}_{2} \mathrm{O}+2 \mathrm{CO}_{2} \rightarrow \mathrm{Mg}^{2+}+\mathrm{Ca}^{2+}+4 \mathrm{HCO}_{3}^{-}[13]$

Increased of $\mathrm{H}^{+}$in the soil samples in form of carbonic will reduced the $\mathrm{pH}$ value as showed in the Fig. 3. 


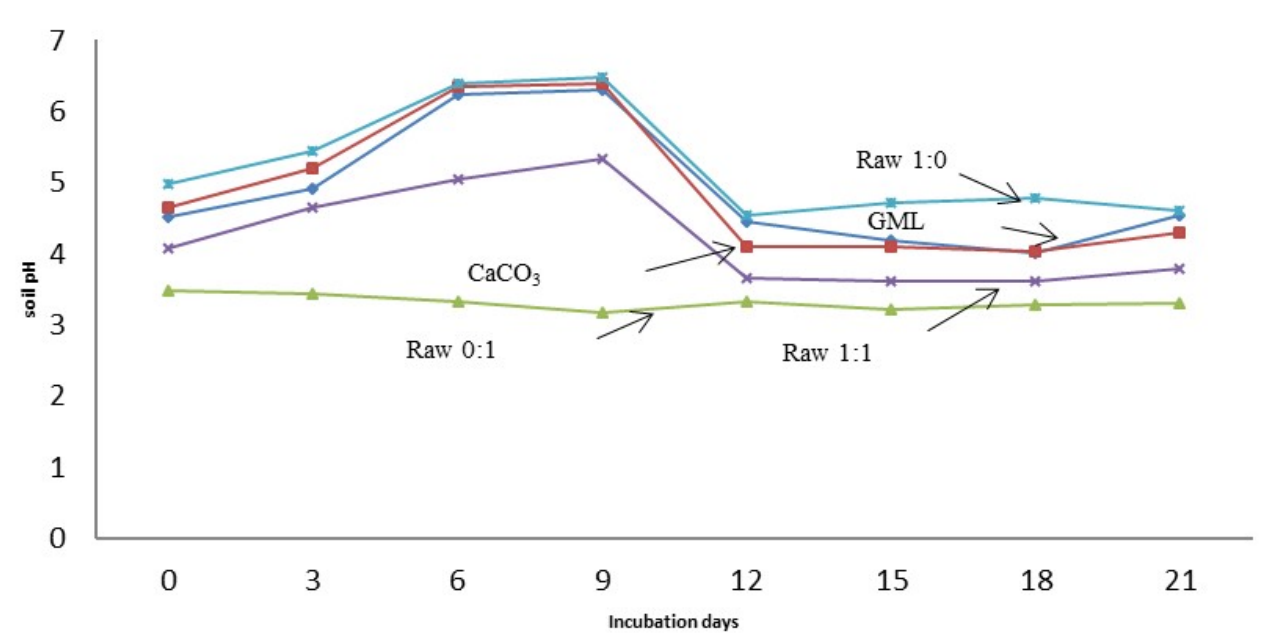

Fig.3. Effect of commercial and raw biogenic composites liming materials $(2 \mathrm{~g} / \mathrm{kg})$ on soil $\mathrm{pH}$

Fig. 4 illustrated effect of calcined biogenic composites liming materials with application rate 2 gram/kilogram soil on soil $\mathrm{pH}$. Calcined BCS (i.e., $900^{\circ} \mathrm{C} 1: 0$ ) increased soil $\mathrm{pH}$ to 6.67 and 6.64 on day 6 and day 9 of incubation, respectively. Content of $\mathrm{CaO}$ (i.e., 61.4\%) in the calcined BCS (i.e., $900^{\circ} \mathrm{C} \mathrm{1:0)} \mathrm{has} \mathrm{played} \mathrm{a} \mathrm{significant} \mathrm{role} \mathrm{in} \mathrm{increasing} \mathrm{the} \mathrm{soil} \mathrm{alkalinity.} \mathrm{The} \mathrm{pH}$ value of soils ameliorated with $900^{\circ} \mathrm{C} 1: 0$ increased from day 0 to day 6 , and decreased from day 12 onwards. The trend of soil $\mathrm{pH}$ for $900^{\circ} \mathrm{C} 1: 0$ showed similar trend as raw 1:0 samples. In contrast, soils amended with calcined composites of 50\% BCS: $50 \%$ PKS (i.e., $900^{\circ} \mathrm{C} 1: 1$ ) has soil $\mathrm{pH}$ value with slightly changes for the entire duration of incubation period. Calcination of biogenic liming materials will make the calcium become less soluble.

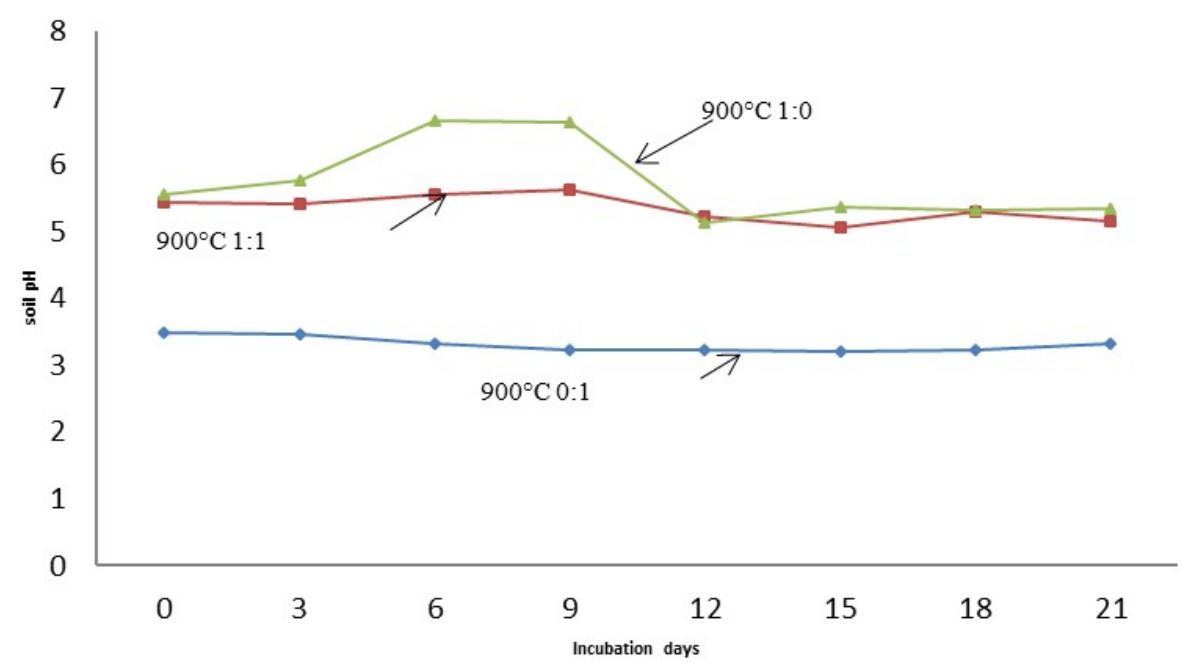

Fig.4. Effect of calcined biogenic composites liming materials $(2 \mathrm{~g} / \mathrm{kg})$ on soil $\mathrm{pH}$ 
Aluminium distributions for soil incubated with commercial liming materials were analyzed using selective sequential extraction analysis and results were illustrated in Fig. 5. Soil without any treatment with commercial liming agent has highest percentage of exchangeable Al $(7.56 \%)$ as compared to other soil treatment. More Al was leached out from soil due to increasing mobility and solubility of Al. In contrast, less Al (2.4\%) was leached out from soil treated with GML, due to lower solubility and decreasing mobility of $\mathrm{Al}$ at higher soil $\mathrm{pH}$ [14].

Soil amended with GML has highest percentage of Al for Fraction 2 (Bound to carbonate) compared with another soil treatment with $1.27 \%$. Treatment of soil using $\mathrm{CaCO}_{3}$ has slightly lower percentage of $\mathrm{Al}$ for Fraction 2 (Bound to carbonate) with $0.81 \%$.

Fraction 5 (Residual) showed that soil treated with GML has more residues of Al with $89.3 \%$. Only about $10.7 \%$ of $\mathrm{Al}$ present in the soil reacted with previous four fractions of selective sequential extraction (Fraction 1-4). Control sample (soil 100\%) has less residues of Al with $86.45 \%$. More than $13.55 \%$ of $\mathrm{Al}$ present in the soil able to be extract out with previous four fractions of selective sequential extraction (Fraction 1-4).

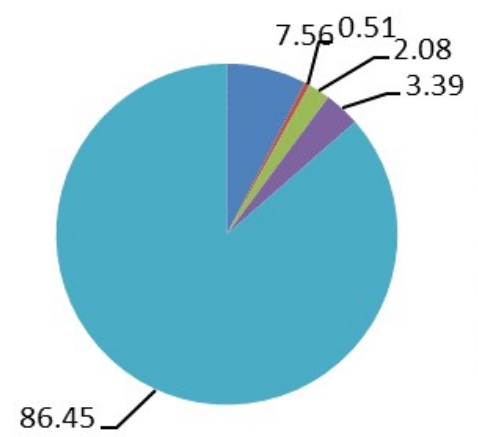

(a)

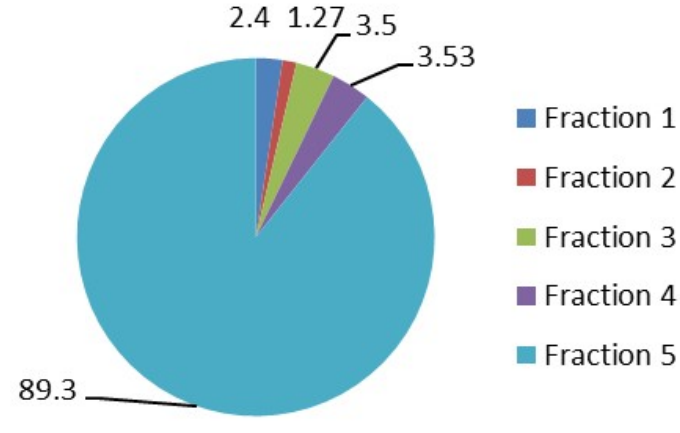

(b) 


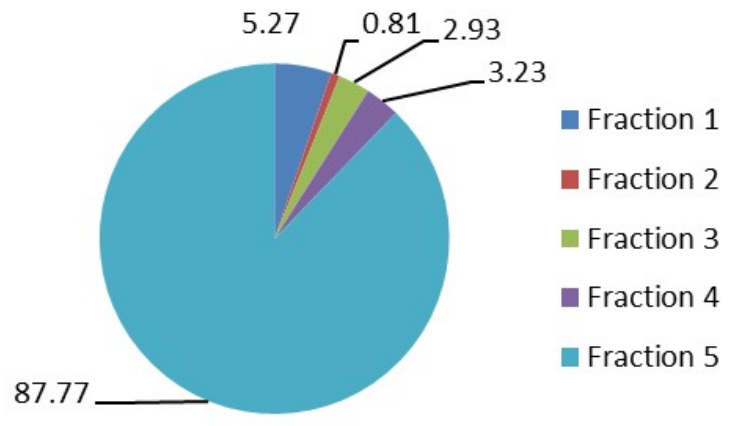

(c)

Fig.5. Aluminium distributions by Selective Sequential Extraction (SSE) analysis for soil incubated with commercial liming material (a) Soil 100\% (b) GML (c) $\mathrm{CaCO}_{3}$

Fig. 6 illustrates Al distribution for soil incubated with raw and calcined composites ash. Soil treated with raw 0:1 composite has highest percentage of exchangeable Al (12.84\%) as compared to other soil treated with raw composites. More Al was leached out from soil treated with raw 0:1 composite due to increasing mobility and solubility of Al, possibly due to complexation with dissolved organic compounds from PKS [13]. In contrast, less $\mathrm{Al}(0.71 \%)$ was leached out from soil treated with raw 1:0 composite, due to lower solubility and decreasing mobility of $\mathrm{Al}$ at higher soil $\mathrm{pH}$ [14]. Highest percentage of exchangeable aluminium (13.97\%) was detected from soil treated with $900^{\circ} \mathrm{C} 0: 1$ composite ash as compared to control sample (i.e. 7.56\%). Aluminium mobility and solubility may leach out from PKS ash. This supported that the soil samples incubated with $900^{\circ} \mathrm{C} 0: 1$ composite ash were leached out more than the others soil samples. On the other hand, incubated soil with $900^{\circ} \mathrm{C} \mathrm{1:0} \mathrm{composite} \mathrm{ash} \mathrm{has} \mathrm{no} \mathrm{significant} \mathrm{contribution} \mathrm{toward} \mathrm{mobility} \mathrm{of} \mathrm{exchangeable} \mathrm{Al}$ at Fraction 1 with $0 \%$ of aluminium.

Raw 0:1 composite treated soil has highest percentage of $\mathrm{Al}$ for Fraction 2 (Bound to carbonate) compared with another soil treatment using raw composites with $6.53 \%$. Present of carboxyl group from lignocellulosic compounds (lignin) in PKS possibly contributed toward high percentage bound to carbonate in Fraction 2 [15]. Other composites materials i.e. raw 1:0 and raw 1:1 contained calcium carbonate that may not react much with Al, due to stable form of carbonate. Similar condition occurs for both GML and calcium carbonate. Soil treated with $900^{\circ} \mathrm{C}$ 1:1 composite ash has highest percentage of carbonate-bound Al (Fraction 2) 
compared with another soil treatment using calcined composites ash with $10.53 \%$. Carbonation via atmospheric $\mathrm{CO}_{2}$ absorption or lime addition during the soil incubation results in significant carbonate abundance in soil samples. According to [14], Al present in the soil can be influenced by the addition of lime and reacted with the carbonate present. Result obtained from this fraction differ from the Fraction 2 for raw composites materials due to calcination of materials at $900^{\circ} \mathrm{C}$. Calcium carbonate will be converted to calcium oxide when calcined at higher temperature i.e. $900^{\circ} \mathrm{C}$. Calcium oxide in $900^{\circ} \mathrm{C} 1: 0$ and $900^{\circ} \mathrm{C} 1: 1$ composite ash contribute toward high $\mathrm{Al}$ percentage bound to carbonate.

Fraction 5 (Residual) showed that soil treated with raw 1:0 composite has more residues of $\mathrm{Al}$ with $91.33 \%$. Only about $8.67 \%$ of $\mathrm{Al}$ present in the soil reacted with previous four fractions of selective sequential extraction (Fraction 1-4). Raw 0:1 composites treated soil has less residues of $\mathrm{Al}$ with $75.66 \%$. More than $24.34 \%$ of $\mathrm{Al}$ present in the soil able to be extract out with previous four fractions of selective sequential extraction (Fraction 1-4).
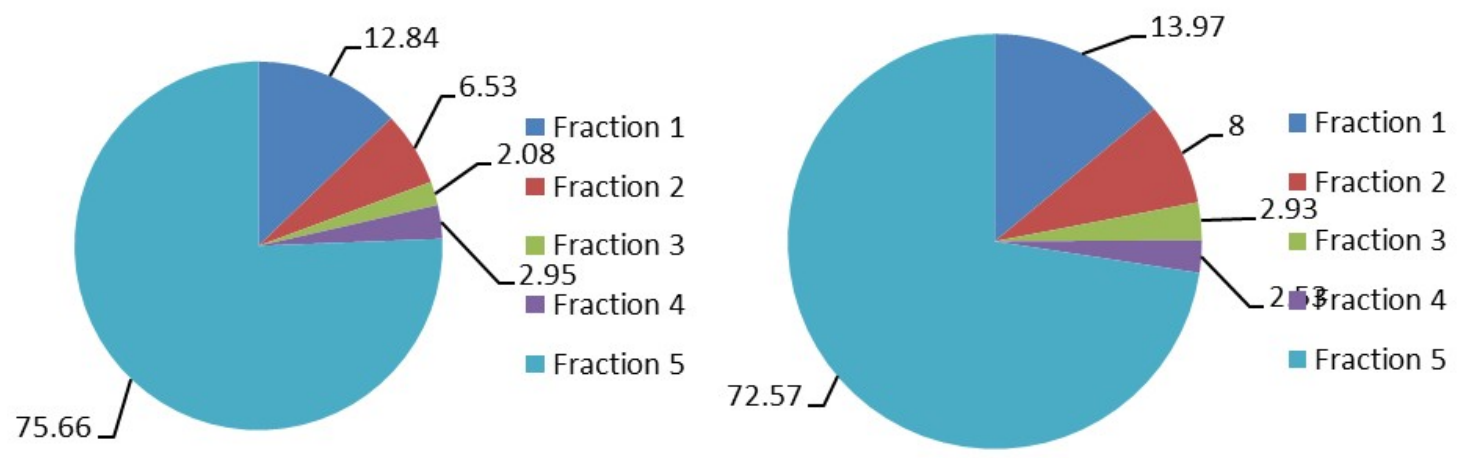

(a)

(b) 


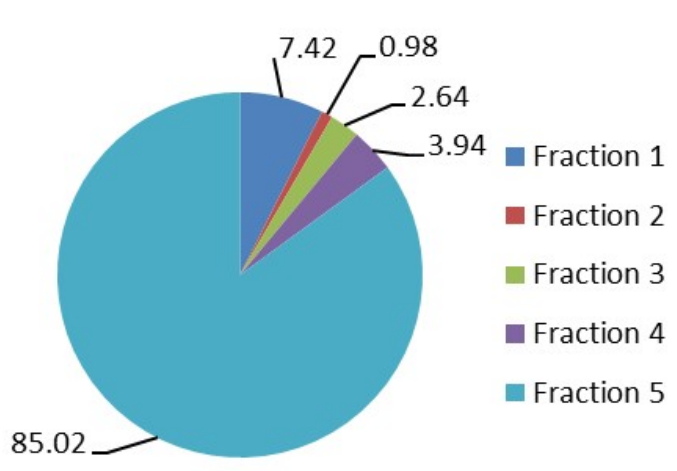

(c)

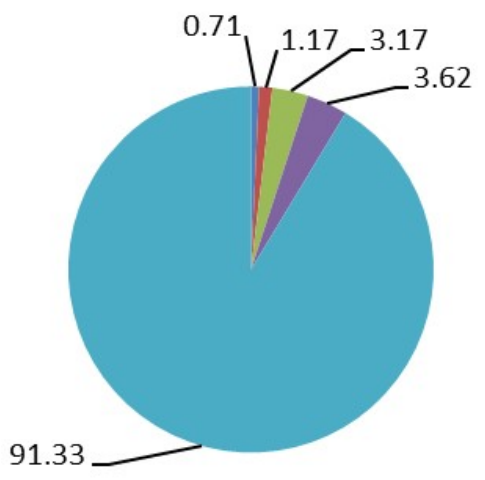

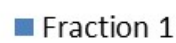

Fraction 2

Fraction 3

Fraction 4

- Fraction 5 (d)

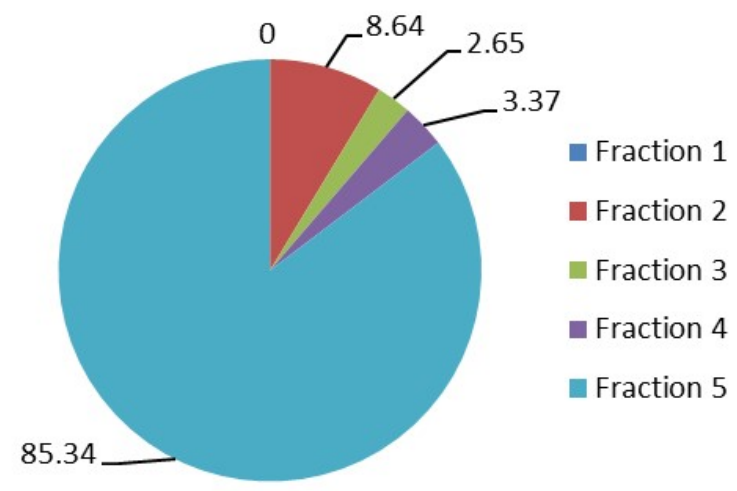

(e)

Fig.6. Aluminium distributions by Selective Sequential Extraction (SSE) analysis for raw and calcined composites ash (a) Raw 0:1 (b) $900{ }^{\circ} \mathrm{C} 0: 1$ (c) Raw $1: 1$ (d) $900{ }^{\circ} \mathrm{C} 1: 1$ (e) Raw 1:0 (f) $900{ }^{\circ} \mathrm{C} 1: 0$

\section{CONCLUSION}

Aluminum in the treated soil was immobilized by the addition of biogenic liming agent. Raw $1: 0$ and $900^{\circ} \mathrm{C} 1: 0$ composites liming material retained residual $\mathrm{Al}$ about $91.33 \%$ and $85.34 \%$ respectively. Raw 1:0 is recommended as biogenic liming agent to immobilized aluminum due to its capability to retain higher $\mathrm{Al}$ in the residual form as compared to other liming materials. Amelioration of soil with 100\% palm kernel shell (PKS) did not result in significant outcome as more exchangeable aluminum leached out at Fraction 1 of selective sequential extraction (SSE). 


\section{ACKNOWLEDGEMENTS}

We would like to thank Ministry of Higher Education for research funding support under Research Acculturation Collaborative Effort (RACE) (Phase 3, 2014). Deepest gratitude expressed to the paddy farmer at Kampung Jilid 5 and Kampung Padang Tok Sura, Merbok, and Kedah, Malaysia for their assistance and permission during soil sampling process. In addition, appreciation to the management of FELDA Palm Industries Sdn. Bhd., Kilang Sawit Felda Jengka 21, Bandar Pusat Jengka, Pahang and Perlis Dolomite Industries Sdn.Bhd., Pusat Perniagaan Adenium Seksyen BB5, 48300 Bukit Beruntung, Selangor in providing raw materials for experimental purposes for this study. Last but not least, Associate Professor Dr. Ahmad Saat and Environmental Radiation Research Laboratory, Institute of Science, Universiti Teknologi MARA in assistance for instrumental analysis.

\section{REFERENCES}

[1] Anderson N P, Hart J M, Sullivan D M, Horneck D A, Pirelli G J, Christensen N W. Applying lime to raise soil $\mathrm{pH}$ for crop production (Western Oregon). Corvallis: Oregon State University, 2013

[2] Gazey C, Ryan L. Effects of soil acidity. 2016, https://www.agric.wa.gov.au/soil-acidity/effects-soil-acidity

[3] Shamshuddin J, Panhwar Q A, Shazana M A, Elisa A A, Fauziah C I, Naher U A. Improving the productivity of acid sulfate soils for rice cultivation using limestone, basalt, organic fertilizer and/or their combinations. Sains Malaysiana, 2016, 45(3):383-392

[4] Shamshuddin J, Fauziah C I, Anda M, Kapok J, Shazana M A. Using ground basalt and/or organic fertilizer to enhance productivity of acid soils in Malaysia for crop production. Malaysian Journal of Soil Sciences, 2011, 15(1):127-146

[5] Elisa A A, Ninomiya S, Shamshuddin J, Roslan I. Alleviating aluminum toxicity in an acid sulfate soil from Peninsular Malaysia by calcium silicate application. Solid Earth, 2016, $7(2): 367-374$

[6] Chen L, Lin L, Cai G, Sun Y, Huang T, Wang K, Deng J. Identification of nitrogen, phosphorus, and potassium deficiencies in rice based on static scanning technology and hierarchical identification method. Plos One, 2014, 2014, 9(11):1-17 
[7] Berkelaar E. The effect of aluminum in acidic soils on plant growth. ECHO Development Notes, 2001, 71:1-3

[8] Suswanto T, Shamshuddin J, Omar S S, Mat P, Teh C B. Alleviating an acid sulfate soil cultivated to rice (Oryza sativa) using ground magnesium limestone and organic fertilizer. Jurnal Ilmu Tanah dan Lingkungan, 2007, 9(1):1-9

[9] Tobergte D R, Curtis S. Cation exchange capacity of soils (Sodium Acetate). Journal of Chemical Information and Modeling, 2013, 53(9):1689-1699

[10] Tessier A, Campbell P G, Bisson M. Sequential extraction procedure for the speciation of particulate trace metals. Analytical Chemistry, 1979, 51(7):844-851

[11] Ashraf M A, Maah M J, Yusoff I. Chemical speciation and potential mobility of heavy metals in the soil of former tin mining catchment. The Scientific World Journal, 2012, 2012:1-11

[12] Tack F M, Verloo M G. Single extractions versus sequential extraction for the estimation of heavy metal fractions in reduced and oxidised dredged sediments. Chemical Speciation and Bioavailability, 1999, 11(2):43-50

[13] West T O, McBride A C. The contribution of agricultural lime to carbon dioxide emissions in the United States: Dissolution, transport, and net emissions. Agriculture, Ecosystems and Environment, 2005, 108(2):145-154

[14] Rodgers K J, Hursthouse A, Cuthbert S. The potential of sequential extraction in the characterisation and management of wastes from steel processing: A prospective review. International Journal of Environmental Research and Public Health, 2015, 12(9):11724-1755 [15] Hasnan M A, Husseinsyah S, Ying L B, Rahman M F. Chemical modification of palm kernel shell filled polylactic acid biocomposite films. BioResources, 2016, 11(3):6639-6648

\section{How to cite this article:}

Salleh N. M. A. and Yong S. K. Speciation of Aluminum in Acid Sulfate Soil Ameliorated With Biogenic Liming Composites of Blood Cockle Shell (BCS) and Palm Kernel Shell (PKS). J. Fundam. Appl. Sci., 2017, 9(6S), 965-980. 